\author{
Adrian Borys* \\ ORCID: 0000-0002-1620-285X
}

Uniwersytet Wrocławski

DOI: $10.19195 / 1733-5779.28 .9$

\title{
Przyczynowość hipotetyczna. \\ Problematyka ustalenia zakresu odpowiedzialności deliktowej w sytuacji wystąpienia tak zwanej przyczyny rezerwowej (causa superveniens)
}

\section{JEL Classification: K150}

Słowa kluczowe: odpowiedzialność deliktowa, przyczyna rezerwowa (causa superveniens), przyczynowość hipotetyczna, dynamiczna koncepcja szkody, metoda obiektywna ustalania szkody, metoda dyferencyjna ustalania szkody, zasada pełnego odszkodowania

Keywords: liability for tort, reserve reason (causa superveniens), hypothetical causality, dynamic concept of damage, objective method of determining damages, differential method of determining damages, principle of full compensation

Abstrakt: Opracowanie jest przedstawieniem problematyki przyczynowości hipotetycznej w odniesieniu do związku przyczynowego oraz ustalania rozmiaru szkody. Zawarto w nim poglądy doktryny — zarówno dopuszczające możliwość uwzględnienia przyczyny rezerwowej podczas ustalania rozmiaru szkody, jak i negujące taką możliwość. Problematyka przyczyny rezerwowej jako czynnika wpływającego na rozmiar szkody została zaprezentowana z perspektywy metody obiektywnej oraz metody dyferencyjnej ustalania rozmiaru szkody. Autor wykazał, że ustalanie rozmiaru szkody jedynie metodą dyferencyjną prowadzi do wyniku sprzecznego ze społeczną oceną aksjologiczną, który nie może zostać uznany za wiążący. Zanegowanie przez autora dominacji metody dyferencyjnej nie jest jednak zaprzeczeniem dynamicznego charakteru szkody. Zauważając problem szkody rozwojowej oraz odpowiedzialności za utracone korzyści, autor przychyla się do stanowiska, zgodnie z którym rozmiar szkody ustalony metodą obiektywną — stanowiący minimalny rozmiar szkody — powinien zostać skorygowany metodą dyferencyjną. Dlatego

\footnotetext{
* Opiekun naukowy (Scientific Tutor) — dr hab. Izabella Gil, prof. nadzw. UWr
} 
też przyczyna rezerwowa (causa superveniens) nie może zostać uwzględniona jako okoliczność zmniejszająca zakres obowiązku naprawienia szkody przez podmiot odpowiedzialny za zdarzenie podstawowe.

\title{
Hypothetical causality. The problem of determining the scope of tort liability, in the situation of the so-called reserve reason (causa superveniens)
}

\begin{abstract}
The study presents the problems of hypothetical causation from the point of view of proximate cause and determining the extent of damage. The paper presents the views of the doctrine, both allowing the possibility of taking into account the reserve reason (causa superveniens) when determining the extent of damage, as well as denying such a possibility. The issue of the reserve reason as a factor affecting the extent of damage was presented from the perspective of the objective method and the differential method of determining the extent of damage. The author has shown that determining the extent of damage only by means of the method differentially leads to a result contrary to the social axiological assessment, which can't be considered binding. The author negated domination of the differential method. However, doesn't contradict the dynamic character of the damage. Noting the problem of development damage and liability for lost profits, the author agrees to the position according to which the extent of damage determined by the objective method - constituting the minimum extent of damage - should be corrected using the differential method. Therefore, reserve reason (causa superveniens) can't lead to a reduction in the scope of the obligation to repair the damage by the entity responsible for the basic event.
\end{abstract}

\section{Uwagi wstępne}

Zagadnienie przyczynowości hipotetycznej jest jednym z istotniejszych problemów prawa odszkodowawczego. Zagadnienie to jest związane z odpowiedzią na pytanie, czy pozwany o naprawienie szkody wyrządzonej przez realne zdarzenie szkodzące może skutecznie uwolnić się od odpowiedzialności lub ją ograniczyć przez wykazanie, że uszczerbek, o którego rekompensatę wystąpiono w pozwie, powstałby również, gdyby obciążające pozwanego realne zdarzenie szkodzące nie wystąpiło, a miałoby miejsce inne późniejsze zdarzenie, będące wobec realnej przyczyny tak zwaną przyczyną rezerwową lub zapasową (causa superveniens).

Przyczyną rezerwową jest zdarzenie bezsprzecznie warunkujące powstanie szkody, gdyby w rozważanym łańcuchu kauzalnym nie wystąpiło realne zdarzenie szkodzące, uzasadniające odpowiedzialność cywilną ${ }^{1}$ Szkoda, która powstałaby w wyniku wystąpienia przyczyny rezerwowej, mogłaby być szkodą większych rozmiarów niż szkoda powstała w wyniku zdarzenia podstawowego. Hipotetyczna szkoda, która powstałaby w wyniku wystąpienia przyczyny rezerwowej, implikowałaby również powstanie szkody wyrządzonej realnym zdarzeniem szkodzącym. Oznacza to, że przez pojęcie przyczynowości hipotetycznej należy rozumieć sytuację, w której szkoda powstałaby również bez wystąpienia zdarzenia podstawowego, ponieważ zostałaby wywołana przez inne nieuniknione zdarzenie, to znaczy

${ }^{1}$ H. Stoll, Kausalzusammenhang und Normzweck im Deliktrecht, Tübingen 1968, s. 42.

Studenckie Prace Prawnicze, Administratywistyczne i Ekonomiczne 28, 2019

(C) for this edition by CNS 
przyczynę rezerwową ${ }^{2}$. W rzeczywistości jednak przyczyna rezerwowa nie mogła oddziaływać na sferę dóbr poszkodowanego w zakresie, w jakim powstała szkoda w wyniku uprzedniego wystąpienia realnego zdarzenia, warunkującego powstanie odpowiedzialności cywilnej. Koncepcja ta określana jest w doktrynie mianem przyczynowości hipotetycznej (wyprzedzającej ${ }^{3}$ ), ponieważ wnioskowanie w niej zawarte nie jest oparte na zdarzeniach, które rzeczywiście wystąpiły, lecz jedynie na zdarzeniach, które hipotetycznie mogłyby się wydarzyć ${ }^{4}$.

W celu lepszego zrozumienia istoty przyczynowości hipotetycznej warto podać przykład. Złodziej dokonuje kradzieży samochodu znajdującego się w garażu, dochodzi do wypadku i samochód zostaje uszkodzony. Następnie dochodzi do pożaru garażu właściciela samochodu, spowodowanego przestarzałą instalacją elektryczną. Realnym zdarzeniem podstawowym, stanowiącym podstawę odpowiedzialności cywilnej, jest w tym wypadku kradzież i uszkodzenie samochodu w wyniku wypadku, z kolei przyczyną rezerwową jest samoczynny pożar garażu ${ }^{5}$. Gdyby nie wystąpiło zdarzenie podstawowe, to i tak w wyniku działania przyczyny rezerwowej doszłoby do uszkodzenia samochodu i to nawet w większym zakresie. Czy w takim wypadku podmiot, który dokonał kradzieży i uszkodził pojazd, ponosi odpowiedzialność za szkodę, która i tak niezaprzeczalnie nastąpiłaby, gdyby nie podjął działania? Wskazać należy, że przyczyna hipotetyczna nie może być wynikiem działania bezpośredniego sprawcy szkody, czyli sprawcy realnego zdarzenia szkodzącego. Odnosząc się do podanego przykładu, można stwierdzić, że złodziej, dokonując włamania, równocześnie uszkodziłby instalację elektryczną, w następstwie czego doszłoby do pożaru garażu. W takim wypad$\mathrm{ku}$, mimo iż złodziej nie jest bezpośrednim sprawcą pożaru, to pożar garażu jest konsekwencją jego działania. W tym stanie faktycznym pożar nie może zostać uznany za przyczynę rezerwową, gdyż nie wystąpiłby niezależnie od wystąpienia realnego zdarzenia szkodzącego. Istota przyczyny rezerwowej (causa superveniens) polega bowiem na tym, że jej wystąpienie zostaje udaremnione przez wystąpienie realnego zdarzenia szkodzącego, ale sama hipotetyczna możliwość jej wystąpienia musi być niezależna od zdarzenia szkodzącego ${ }^{6}$.

W piśmiennictwie i w judykaturze prezentowane były różne przykłady obrazujące konstrukcję przyczynowości hipotetycznej. Można wskazać chociażby

2 M. Kaliński, [w:] System Prawa Prywatnego, t. 6. Prawo zobowiazań - czesść ogólna, red. A. Olejniczak, Warszawa 2014, s. 147.

3 Zob. J. Jastrzębski, O wyprzedzającej przyczynowości, „Kwartalnik Prawa Prywatnego” 2003, nr 3, s. 612 n.

4 P. Sobolewski, Komentarz do art. 361, [w:] Kodeks cywilny. Komentarz, red. K. Osajda, wersja elektroniczna, uwaga 83, SIP Legalis.

${ }^{5}$ H. Nederlander, Schadensersatz bei hypothetischen Schadenserreignissen, „Archiv fur die civilistiche Praxis" 1954, nr 153, s. 41; J. Jastrzębski, op. cit., s. 635.

6 J. Jastrzębski, Glosa do wyroku Sądu Najwyższego z dnia 2 marca 2006 r., sygn. akt I CSK 90/05, „Palestra” 2007, nr 3/4, s. 330. 
następujące: poszkodowany poniósł śmierć w wyniku postrzelenia (realne zdarzenie szkodzące). Przed zdarzeniem zażył jednak taką dawkę substancji trującej, która z pewnością spowodowałaby jego śmierć (przyczyna rezerwowa), jednak wcześniej nastąpił śmiertelny strzał ${ }^{7}$; pracownik uległ wypadkowi przy pracy, który ograniczył jego zdolności zarobkowe (realne zdarzenie szkodzące), następnie w wyniku innego schorzenia niezależnego od wypadku przy pracy utracił całkowicie zdolność do pracy (przyczyna rezerwowa) ${ }^{8}$; bank przeprowadził skutecznie egzekucję z majątku kredytobiorcy na podstawie tytułów egzekucyjnych pozbawionych klauzuli wykonalności (realne zdarzenie szkodzące), broniąc się przed odpowiedzialnością odszkodowawczą, bank powoływał się na przyczynę rezerwową, wskazując, że uszczerbek w majątku kredytobiorcy powstałby również w wypadku prawidłowo wystawionych tytułów wykonawczych (tak zwanego legalnego zachowania alternatywnego) ${ }^{9}$. Kolejnym przykładem tak zwanego legalnego zachowania alternatywnego jest następujący stan faktyczny: poszkodowany został pozbawiony prawa własności nieruchomości w 1954 roku w wyniku nielegalnego działania organu administracji, Skarb Państwa w celu uniknięcia odpowiedzialności odszkodowawczej powołał jako przyczynę rezerwową okoliczność, iż w latach późniejszych nastąpiłoby legalne wywłaszczenie przedmiotowej nieruchomości ${ }^{10}$.

W dalszej części opracowania udzielona zostanie odpowiedź na pytanie, w jakim zakresie poniesie odpowiedzialność sprawca szkody wywołanej zdarzeniem podstawowym, a w konsekwencji w jakim zakresie przyczyna rezerwowa zwalnia z odpowiedzialności za szkodę wywołaną realnym zdarzeniem szkodzącym. Przedstawiona zostanie również kwestia związku przyczynowego między szkodą, zdarzeniem uzasadniającym odpowiedzialność a przyczyną rezerwową.

\section{Ustalanie związku przyczynowego między realnym zdarzeniem szkodzącym a szkodą w kontekście przyczyny rezerwowej}

Poglądy judykatury i doktryn dotyczące dopuszczalności stosowania konstrukcji tak zwanej przyczynowości hipotetycznej przeszły istotną ewolucję. Problematyka przyczynowości hipotetycznej czy też przyczyny rezerwowej (causa superveniens) rozważana była w doktrynie jako problem ustalenia związku przyczynowego $^{11}$. Wskazywano, że tak zwana przyczyna rezerwowa nie powinna

7 A. Koch, Metodologiczne zagadnienia zwiąku przyczynowego w prawie cywilnym, Poznań 1975, s. 111.

${ }^{8}$ Wyrok SN z 16 lutego 1965 roku, sygn. akt I PR 330/64, Legalis nr 109421.

9 Wyrok SN z 14 stycznia 2005 roku, sygn. akt III CK 193/04, Legalis nr 69525.

10 Wyrok SN z 29 kwietnia 2010 roku, sygn. akt IV CSK 467/09, Legalis nr 237026.

11 B. Lewaszkiewicz-Petrykowska, Wyrządzenie szkody przez kilka osób, Warszawa 1978, s. 79; J. Napierała, Utracony zysk jako postać szkody w prawie niemieckim, „Ruch Prawniczy, Ekonomiczny i Socjologiczny” 1991, nr 4, s. 74; idem, Z problematyki lucrum cesans $w$ obrocie 
być uwzględniana ${ }^{12}$. W rozważaniach doktrynalnych podkreślano, że określając adekwatny związek przyczynowy, co do zasady należy brać pod uwage jedynie te zdarzenia, które w konkretnym stanie faktycznym rzeczywiście wystąpiły. Natomiast zdarzenia hipotetyczne, mogące przypuszczalnie powstać, można uwzględnić jedynie wyjątkowo w wypadku odpowiedzialności za szkody wyrządzone zaniechaniem lub $\mathrm{w}$ celu ustalenia utraconych przez poszkodowanego korzyści (lucrum cesans) czy zwiększonych wydatków ${ }^{13}$. Wskazywano, że ustalając zakres odpowiedzialności odszkodowawczej, nie można uwzględniać przyczyny zapasowej, która w konsekwencji prowadzi do ograniczenia bądź wyłączenia odpowiedzialności za realne zdarzenie szkodzące ${ }^{14}$.

Rozważania dotyczące przyczynowości hipotetycznej na płaszczyźnie związku przyczynowego wskazywały, że nawet jeśli przyczyna rezerwowa mogłaby doprowadzić do powstania takiej samej lub większej szkody, nie podważa to związku przyczynowego między wystąpieniem szkody a realnym zdarzeniem szkodzącym ${ }^{15}$ uwzględnionym $\mathrm{w}$ hipotezie normy prawnej. Uwzględnienie zatem przyczyny rezerwowej nie może być utożsamiane z negatywnym wynikiem testu sine qua non ${ }^{16}$. Należy jednak się zastanowić, czy przyjęcie, że wystąpienie przyczyny rezerwowej nie unicestwia łańcuchu kauzalnego między realnym zdarzeniem szkodzącym a powstałą szkodą, nie przekreśla możliwości uwzględnienia wpływu przyczyny rezerwowej na rozmiar szkody.

\section{Określenie rozmiaru szkody w kontekście przyczyny rezerwowej}

Zagadnienie przyczynowości hipotetycznej rozpatrywane jest również jako problem ustalenia zakresu odpowiedzialności — rozmiaru szkody ${ }^{17}$. Pojawienie

uspołecznionym, „Ruch Prawniczy, Ekonomiczny i Socjologiczny” 1983, nr 4, s. 51; Z. Banaszczyk, [w:] Kodeks cywilny. Komentarz, t. 1, red. K. Pietrzykowski, Warszawa 2013, s. 993 n.; K. Zagrobelny, [w:] Kodeks cywilny. Komentarz, red. E. Gniewek, P. Machnikowski, Warszawa 2016, s. 646.

12 A. Szpunar, Ustalenie odszkodowania w prawie cywilnym, Warszawa 1975, s. 42-43; idem, Odszkodowanie za szkodę majątkowa, Bydgoszcz 1998, s. 37-38; B. Lewaszkiewicz-Petrykowska, op. cit., s. 79; G. Bieniek, Odpowiedzialność cywilna za wypadki drogowe, Warszawa 2007, s. 158; K. Zagrobelny, op. cit., s. 573.

13 T. Wiśniewski, [w:] Komentarz do kodeksu cywilnego. Księga trzecia. Zobowiazania, t. 1, red. G. Bieniek, Warszawa 2009, s. 79; wyrok SN z 10 lutego 2009 roku, sygn. akt II PK 142/08, Legalis nr 238932; wyrok SN z 11 marca 2009 roku, sygn. akt I CSK 363/08, Legalis nr 244054.

14 Zob. A. Szpunar, Ustalenie..., s. 43; T. Wiśniewski, op. cit., s. 79; K. Zagrobelny, op. cit., s. $679-680$.

15 A. Koch, Zwiąek przyczynowy jako podstawa odpowiedzialności w prawie cywilnym, Warszawa 1975, s. 78-79; A. Szpunar, Ustalenie..., s. 43.

16 A. Koch, Komentarz do art. 361, [w:] Kodeks cywilny, t. 1. Komentarz do art. 1-449, red. M. Gutowski, wersja elektroniczna, uwaga 34-36, SIP Legalis.

17 J. Jastrzębski, O wyprzedzającej..., s. 612; M. Kaliński, Szkoda na mieniu i jej naprawienie, Warszawa 2008, s. 407; M. Kaliński, [w:] System Prawa Prywatnego, t. 6, s. 147-148.

Studenckie Prace Prawnicze, Administratywistyczne i Ekonomiczne 28, 2019

C for this edition by CNS 
się przyczyny rezerwowej może wpływać na stan dóbr i majątku poszkodowanego. Rozmiar szkody mógłby ulec zmianie w rezultacie działania późniejszego hipotetycznego czynnika szkodzącego. W konkretnym stanie faktycznym przyczyna rezerwowa, będąca dodatkowym czynnikiem szkodzącym, może wywierać realny wpływ na stan majątku poszkodowanego, który został już wcześniej uszczuplony przez realne działanie szkodzące, to jest przyczynę będącą podstawą obowiązku odszkodowawczego. Końcową granicę czasową, w jakiej może wystąpić przyczyna rezerwowa, wyznacza moment ustalenia rozmiaru odszkodowania przez wyrok sądu albo chwila porozumienia ugodowego stron ${ }^{18}$.

Za dopuszczalnością powołania się przez sprawcę szkody na przyczynę rezerwową (causa superveniens) jako pierwszy opowiedział się T. Dybowski, ograniczając jednak taką możliwość do przypadków odpowiedzialności za szkody rozwojowe obejmujące kolejne uszczerbki związane z uszkodzeniem ciała lub rozstrojem zdrowia oraz szkody w postaci utraconych przez poszkodowanego korzyści (lucrum cesans) ${ }^{19}$. Dybowski ograniczał możliwość powoływania się na przyczynę rezerwową tylko do przypadków, w których przyczyna rezerwowa stanowiłaby zdarzenie uzasadniające odpowiedzialność innej osoby, a osoba ta zostałaby bezspornie obciążona skutkami tego późniejszego zdarzenia ${ }^{20}$. Odmówiono więc możliwości powołania się na przyczynę rezerwową stanowiącą tak zwany przypadek. Ze względu na zasadę, że właściciel rzeczy ponosi skutki zdarzenia przypadkowego powodującego uszkodzenie lub zniszczenie rzeczy (casus sentit dominus), dopuszczenie możliwości powoływania się na przyczynę rezerwową stanowiącą tak zwany przypadek (zdarzenie losowe) przez sprawcę szkody, odpowiedzialnego za realne zdarzenie szkodzące, oznaczałoby pozbawienie poszkodowanego prawa do restytucji powstałej szkody.

W doktrynie polskiego prawa cywilnego materialnego pogląd o dopuszczalności ograniczenia odpowiedzialności odszkodowawczej ze względu na hipotetyczną przyczynę rezerwową reprezentuje przede wszystkim J. Jastrzębski. Jego zdaniem możliwość uwzględnienia przyczyny rezerwowej w zakresie wyznaczania rozmiaru szkody wynika z charakteru świadczenia odszkodowawczego, a w szczególności z koncepcji dynamicznego pojmowania szkody ${ }^{21}$. Zgodnie z metodą dyferencyjną szkoda rozumiana jest jako różnica między rzeczywistym stanem dóbr poszkodowanego po ich naruszeniu a stanem hipotetycznym, który istniałby, gdyby realne zdarzenie szkodzące nie nastąpiło.

Jedną z funkcji odpowiedzialności odszkodowawczej jest funkcja kompensacyjna, która niejako przerzuca ciężar doznanej przez poszkodowanego szkody na

18 M. Kaliński, Szkoda..., s. 414, 418-419.

19 Zob. T. Dybowski, [w:] System prawa cywilnego, t. 3, cz. 1, red. Z. Radwański, Wrocław 1981, s. 261-262.

20 Ibidem.

21 J. Jastrzębski, O wyprzedzającej..., s. 612; idem, Glosa ..., s. 329. 
inny podmiot, będący sprawcą szkody, ponieważ w społecznej ocenie aksjologicznej niezasadne byłoby obciążenie szkodą samego poszkodowanego ${ }^{22}$, zwłaszcza że zdarzenie będące przyczyną szkody co do zasady wiąże się z wystąpieniem obiektywnej nieprawidłowości. W ujęciu metody dyferencyjnej preferowanej przez Jastrzębskiego świadczenie odszkodowawcze ma za zadanie zapewnić taki sam stan majątku poszkodowanego, jaki hipotetycznie istniałby, gdyby nie wystąpiło realne zdarzenie szkodzące ${ }^{23}$. Metoda ta wymaga zrekonstruowania hipotetycznego stanu majątku poszkodowanego, a zatem konieczne jest uwzględnienie wszelkich późniejszych w stosunku do realnego zdarzenia szkodzącego okoliczności, które miałyby wpływ na hipotetyczny przebieg procesów kauzalnych w tym przyczyny rezerwowej. Hipoteczny stan majątku poszkodowanego w tym ujęciu ustala się z uwzględnieniem sprawdzonych ex post warunków, w jakich znajdowałby się poszkodowany ${ }^{24}$. W tym celu należy wrócić do stanu sprzed realnego zdarzenia szkodzącego i otworzyć ciąg kauzalny z pominięciem realnego zdarzenia szkodzącego. W przedstawionym ujęciu hipotetyczny stan majątku poszkodowanego konstruowany jest z uwzględnieniem wszelkich zdarzeń — zarówno zwiększających, jak i zmniejszających rozmiar szkody. Wynika to z przyjętej definicji szkody i odszkodowania zgodnie z metodą dyferencyjną ${ }^{25}$. Wracając do przykładu wskazanego na początku opracowania, należy wskazać, że stan majątku poszkodowanego po wystąpieniu realnego zdarzenia szkodzącego uszczuplił się o uszkodzenia, jakie powstały w samochodzie. Natomiast dokonując hipotetycznej rekonstrukcji stanu majątku poszkodowanego z pominięciem realnego zdarzenia szkodzącego, dojdziemy do wniosku, że stan majątku poszkodowanego uszczupliłby się o wartość samochodu, który uległby całkowitemu zniszczeniu. Porównanie stanu rzeczywistego ze stanem hipotetycznym zgodnie z metodą dyferencyjną prowadzi do wniosku, że we wskazanym przykładzie szkoda w ogóle nie wystąpiła. Rezultat zastosowania metody dyferencyjnej pozostaje w tym przypadku sprzeczny ze społeczną oceną aksjologiczną, gdyż mimo wystąpienia zdarzenia obiektywnie nieprawidłowego — kradzieży i zniszczenia samochodu — podmiot odpowiedzialny nie będzie zobowiązany do rekompensaty, a ciężar powstałej szkody zostanie przerzucony na właściciela samochodu. Dlatego moim zdaniem posłużenie się jedynie metodą dyferencyjną przy określaniu rozmiaru szkody może prowadzić do wypaczeń istoty pojęcia szkody.

$\mathrm{Na}$ dopuszczalność uwzględniania przyczyny rezerwowej przy ustalaniu rozmiaru szkody wskazuje również P. Sobolewski, powołując się na konstrukcję od-

22 M. Kaliński, [w:] System Prawa Prywatnego, t. 6, s. 73.

23 M. Kaliński, O błędach w stosowaniu konstrukcji tzw. causa superveniens, „Przegląd Sądowy" 2013, nr 1, s. 21.

24 Ibidem.

25 J. Jastrzębski, O wyprzedzającej..., s. 631 n.; zob. także M. Kaliński, [w:] System Prawa Prywatnego, t. 6, s. 139 n. 
powiedzialności za przypadek mieszany (casus mixtus). Zgodnie z treścią przepisu art. 478 k.c. w przypadku popadnięcia w zwłokę ze spełnieniem świadczenia dłużnik odpowiedzialny jest za utratę lub uszkodzenie przedmiotu świadczenia, chyba że utrata lub uszkodzenie nastąpiłoby także wtedy, gdyby świadczenie zostało spełnione w czasie właściwym. Możliwe jest zatem uniknięcie odpowiedzialności dłużnika przez wykazanie, że szkoda powstałaby także w przypadku zachowania zgodnego z prawem. W tej sytuacji zachowanie zgodne z prawem zdaniem wskazanego autora stanowi przyczynę rezerwową szkody, która prowadzi do wyłączenia odpowiedzialności ${ }^{26}$. Taka argumentacja nie jest jednak do zaakceptowania ze względu na przedstawioną na wstępie definicję przyczyny rezerwowej. Zachowanie zgodnie z prawem, czyli należyte wykonanie zobowiązania, nie stanowi w tym wypadku przyczyny rezerwowej, która powinna być przyczyną następczą względem realnego zdarzenia szkodzącego. W celu lepszego zobrazowania omawianej sytuacji rozważmy następujący przykład: mechanik popada w zwłokę z wydaniem pojazdu, który zostaje dłużej w warsztacie. W wyniku nieostrożnej zabawy fajerwerkami właściciel sąsiedniej posesji doprowadza do pożaru warsztatu (realne zdarzenie szkodzące), w którego wyniku pojazd zostaje całkowicie zniszczony. W celu uwolnienia się od odpowiedzialności mechanik powinien wykazać, że do zniszczenia pojazdu doszłoby również w wypadku jego terminowego wydania, to znaczy powinien wykazać hipotetyczną przyczynę powstania szkody, na przykład samoistne zawalenie się garażu właściciela pojazdu. Jednakże ta hipotetyczna przyczyna nie stanowi przyczyny rezerwowej. Gdyby w przedstawionym przykładzie nie wystąpiło realne zdarzenie szkodzące, to przyczyna hipotetyczna zawalenie się garażu — w żadnym wypadku nie spowodowałaby szkody. Błędne w mojej ocenie podciągniecie odpowiedzialności za casus mixtus pod konstrukcję przyczyny rezerwowej wynika z uznania za realną przyczynę szkodzącą samego faktu popadnięcia w zwłokę przez dłużnika. Regulacja dotycząca przypadku mieszanego (casus mixtus) nie dotyczy odpowiedzialności za szkodę spowodowaną samą zwłoką dłużnika, tylko rozszerzenia odpowiedzialności dłużnika za szkodę spowodowaną utratą lub uszkodzeniem przedmiotu świadczenia.

Specyficznym przypadkiem przyczynowości hipotetycznej jest sytuacja, w której przyczyną rezerwową jest inne zachowanie samego sprawcy szkody, będące działaniem legalnym (hipotetyczne alternatywne zachowanie legalne) ${ }^{27}$. Sąd Najwyższy w jednym ze swoich orzeczeń wyraził pogląd dotyczący nieskuteczności obrony pozwanego przed roszczeniem odszkodowawczym, polegającej na wykazaniu, że w wyniku jego późniejszego hipotetycznego zachowania zgodnego $\mathrm{z}$ prawem poszkodowany doznałby co najmniej takiego samego uszczerbku ${ }^{28}$,

26 P. Sobolewski, [w:] Kodeks cywilny. Komentarz, t. 3A, red. K. Osajda, Warszawa 2017, s. 169 .

27 Ibidem.

28 Wyrok SN z 14 stycznia 2005 roku... 
gdy rzeczywiste zachowanie się pozwanego naruszało normy mające zapobiec tej szkodzie. W przedmiotowym stanie faktycznym Sąd Najwyższy rozważał kwestię odpowiedzialności odszkodowawczej banku za szkody spowodowane bezprawnie przeprowadzoną egzekucją wierzytelności (brak nadania bankowemu tytułowi egzekucyjnemu klauzuli wykonalności) ${ }^{29}$. Pozwany bank podnosił, że wierzytelności istniały i mogły zostać wyegzekwowane zgodnie z prawem (tak zwane legalne zachowanie alternatywne). Zdaniem składu orzekającego nawet w wypadku akceptacji samej koncepcji przyczynowości hipotetycznej należy wyłączyć możliwość powoływania się przez sprawcę szkody na własne legalne zachowanie alternatywne ${ }^{30}$. Powołanie się na legalne zachowanie alternatywnie nie może być utożsamiane z legalizacją realnego zachowania szkodzącego, które cechuje się obiektywną nieprawidłowością ${ }^{31}$. Obiektywna nieprawidłowość czynu oznacza, że dane zachowanie należy do kategorii czynów zakazanych przez normę prawną uznaną za obowiązującą ${ }^{32}$. Uznanie danego zachowania za obiektywnie nieprawidłowe jest procesem czysto intelektualnym i polega na subsumpcji danego zachowania (stanu faktycznego) pod określoną normę prawną, czyli na porównaniu rzeczywistego zachowania sprawcy szkody z treścią dyspozycji normy prawnej. Uwzględnienie konstrukcji legalnego zachowania alternatywnego prowadziłoby do sytuacji, w której działanie sprzeczne z prawem nie jest sankcjonowane. Oznaczałoby to domniemaną zgodę na nieprzestrzeganie regulacji prawnych, a w konsekwencji prowadziłoby do osłabienia całego systemu prawnego. Fakt, że działanie zgodne z prawem doprowadziłoby do takiej samej szkody, nie może usprawiedliwiać naruszenia norm prawnych — zwłaszcza w sytuacji zawinionego działania sprawcy szkody. W mojej ocenie istotna jest tu świadomość naruszenia porządku prawnego przez sprawcę szkody, która nie może zostać wyłączona przez przyjęcie konstrukcji legalnego zachowania alternatywnego. Sprawca szkody w chwili realizacji realnego zdarzenia szkodzącego nie miał przecież świadomości, że szkoda wystąpiłaby również przy działaniu legalnym. Akceptowanie koncepcji przyczynowości hipotetycznej nie może in concreto prowadzić do podważenia gwarancyjnej funkcji norm prawnych, naruszonych przez sprawcę szkody ${ }^{33}$. Ze względu na to w pełni zgadzam się ze stanowiskiem Sądu Najwyższego, wskazującym niedopuszczalność wyłączenia odpowiedzialności przez powołanie się, na to, że legalne alternatywne działanie własne wyrządziłoby identyczną szkodę.

29 W okresie, którego dotyczy przedmiotowe orzeczenie, funkcjonowały jeszcze bankowe tytułu egzekucyjne, jednakże w celu prowadzenia postępowania egzekucyjnego bank musiał wystąpić do sądu o nadanie klauzuli wykonalności na wystawiony przez siebie tytuł egzekucyjny.

30 Wyrok SN z 14 stycznia 2005 roku...

31 Zob. M. Wilejczyk, Przyczyna rezerwowa - niedopuszczalny prezent dla osoby odpowiedzialnej za szkodę, „Przegląd Sądowy” 2016, nr 6, s. 77.

32 P. Machnikowski, [w:] System Prawa Prywatnego, t. 6, s. 396.

33 Wyrok SN z 14 stycznia 2005 roku... 
Zdaniem Jastrzębskiego — zwolennika dopuszczalności konstrukcji przyczynowości wyprzedzającej - wykorzystanie tej konstrukcji jest niedopuszczalne, gdy hipotetyczną przyczyną rezerwową szkody byłoby działanie albo zaniechanie innego podmiotu. Zastosowanie koncepcji hipotetycznej przyczynowości w takich warunkach pozbawiałoby poszkodowanego możliwości uzyskania odszkodowania $^{34}$. Rzeczywisty sprawca szkody uwolniłby się od odpowiedzialności przez powołanie się na przyczynę rezerwową, natomiast sprawca hipotetycznego zdarzenia (przyczyny rezerwowej) nie mógłby ponieść odpowiedzialności, ponieważ jego działanie faktycznie nie spowodowało szkody. Wróćmy do początkowego przykładu: złodziej kradnie samochód z garażu, który zostaje zniszczony w wyniku wypadku. Po kradzieży dochodzi do pożaru garażu właściciela pojazdu, spowodowanego przez sąsiada, który nie dochował należytej staranności, spalając na swojej działce gałęzie i liście. Oczywiście sąsiad poniesie odpowiedzialność za szkodę w postaci zniszczenia (spalenia) garażu, natomiast nie można mu przypisać odpowiedzialności za hipotetyczne zniszczenie samochodu, który gdyby nie został skradziony (realne zdarzenie sprawcze), zostałby również zniszczony w wyniku pożaru. Powyższe wyłączenie dopuszczalności stosowania konstrukcji przyczynowości hipotetycznej uwzględnia również M. Kaliński, który wskazuje, że uwzględnienie przyczyny rezerwowej (kształtującej stan hipotetyczny) jest możliwe wówczas, gdy nikt nie ponosiłby odpowiedzialności za tę przyczynę ${ }^{35}$. Autor trafnie zauważa, że w przeciwnym wypadku doszłoby do zwalniania z odpowiedzialności podmiotu, którego obciąża przyczyna zaistniała rzeczywiście, a odpowiedzialność zostałaby przerzucona na osobę, której przypisujemy przyczynę hipotetyczną, co jego zdaniem byłoby „najzupełniej absurdalne"36. Dopuszczalność powołania się na przyczynowość hipotetyczną w celu ograniczenia odpowiedzialności zdaniem wymienionych autorów możliwa jest, jedynie gdy przyczyna rezerwowa stanowi przypadek będący zdarzeniem niezależnym od żądanego podmiotu.

W tym miejscu należy wskazać na niespójność argumentacji zwolenników dopuszczalności konstrukcji przyczynowości wyprzedzającej. Nie dopuszczają oni możliwości powołania się na przyczynę rezerwową, gdy jest ona wynikiem działania osoby trzeciej ze względu na pozbawienie poszkodowanego możliwości restytucji doznanej szkody, nie zauważając jednocześnie, że powołanie się na przyczynę rezerwową w każdym wypadku ogranicza możliwość pełnej restytucji szkody doznanej przez poszkodowanego. W ten sposób naruszona zostaje funkcja

34 J. Jastrzębski, O wyprzedzającej..., s. 615-616, 635.

35 M. Kaliński, O błędach..., s. 22.

36 Ibidem. 
kompensacyjna odpowiedzialności odszkodowawczej, gdyż co do zasady świadczenie odszkodowawcze nie powinno być niższe od rozmiaru szkody ${ }^{37}$.

Krytykiem koncepcji przyczynowości hipotetycznej jest M. Wilejczyk, która podziela przedstawiane w literaturze zastrzeżenia odnośnie do rezultatów metody dyferencyjnej w ustalaniu rozmiarów szkody ${ }^{38}$. Za w pełni uzasadniony należy uznać pogląd o konieczności korygowania rezultatów osiąganych przy ustalaniu rozmiaru szkody metodą dyferencyjną. W tym celu należy odwołać się do założeń obiektywnej metody ustalania szkody. W procesie ustalania szkody punktem wyjścia powinno być zbadanie uszczerbku w stosunku do konkretnego dobra (zgodnie z wymogami metody obiektywnej), a uzyskana w ten sposób wielkość szkody powinna być minimalną wartością, poniżej której nie można zejść, stosując metodę dyferencyjną. W mojej ocenie jedynie zestawienie rezultatów metody obiektywnej oraz metody dyferencyjnej pozwala prawidłowo określić rozmiar szkody. Metoda dyferencyjna pozwala uwzględnić tak zwane szkody rozwojowe oraz utracone korzyści, natomiast uznanie rezultatu zastosowania metody obiektywnej za minimalny rozmiar szkody nie pozwala doprowadzić do rezultatu sprzecznego ze społeczną oceną aksjologiczną. Wobec tego nie można powoływać się na hipotetyczne zdarzenia następcze, które doprowadziłyby do identycznej lub większej szkody ${ }^{39}$. Przyjęcie takich założeń nie podważa dynamicznego charakteru szkody. Jak wskazuje się w literaturze, do czasu ustalenia odszkodowania szkoda jest płynna ${ }^{40}$, a granicę wskazanej płynności wyznacza chwila zapłaty odszkodowania, zamknięcia rozprawy albo zawarcia ugody ${ }^{41}$. Szkoda powstała w wyniku konkretnego zdarzenia niezaprzeczalnie może z biegiem czasu się powiększyć, na przykład gdy ujawnią się nieznane dotąd konsekwencje zdarzenia szkodzącego. Nie można jednak zgodzić się ze stwierdzeniem, że rozmiar szkody z upływem czasu może się zmniejszyć. W mojej ocenie do zmniejszenia rozmiaru odpowiedzialności, zakresu obowiązku naprawienia szkody może dojść poza ustawowo wskazanymi przypadkami jedynie przez zanegowanie istnienia adekwatnego związku przyczynowego między określonymi konsekwencjami zdarzenia a samym zdarzeniem (rzeczywistą przyczyną), a jak zostało wskazane na początku opracowania - samo istnienie przyczyny rezerwowej nie podważa związku przyczynowego między realnym zdarzeniem szkodzącym a szkodą ${ }^{42}$. Dlatego nie widzę żadnych podstaw do ograniczenia zakresu obowiązku napra-

37 A. Szpunar, Odszkodowanie..., s. 133; J. Winiarz, Ustalenie wysokości odszkodowania, Warszawa 1962, s. 73.

38 M. Wilejczyk, op. cit., s. 77.

39 Ibidem.

40 Zob. M. Kaliński, [w:] System Prawa Prywatnego, t. 6, s. 140.

41 J. Jastrzębski, O wyprzedzającej..., s. 638-639.

42 A. Koch, Zwiazek..., s. 78-79; A. Szpunar, Ustalenie..., s. 43; A. Koch, Komentarz..., uwaga $34-36$. 
wienia szkody przez podmiot odpowiedzialny ze względu na istnienie tak zwanej przyczyny rezerwowej.

Stanowisko pośrednie w kwestii dopuszczalności ograniczenia odpowiedzialności ze względu na konstrukcję przyczynowości hipotetycznej zajmują między innymi H. Ciepła, M.R. Sarbiński i K. Sobczyk-Sarbińska, którzy wskazują, że niezasadne jest aprioryczne wykluczenie dopuszczalności powołania się podmiotu odpowiedzialnego na przyczynę rezerwową. Przyczyna rezerwowa (causa superveniens) powinna jednak podlegać wnikliwej analizie w okolicznościach konkretnej sprawy ${ }^{43}$. Jest to stanowisko bardzo zachowawcze, niedające jednoznacznej odpowiedzi.

\section{Wnioski}

Dopuszczalność uwzględniania w ramach ustalania zakresu odpowiedzialności odszkodowawczej (rozmiaru szkody) przyczyny rezerwowej, jaka mogłaby mieć wpływ na hipotetyczny stan majątku poszkodowanego, należy co najmniej ograniczyć. Dominacja dyferencyjnej metody ustalania rozmiaru szkody prowadzi do rezultatów sprzecznych ze społeczną oceną aksjologiczną. Przyczyna rezerwowa jako zdarzenie czysto hipotetyczne obarczona jest zawsze wątpliwościami dotyczącymi możliwości jej wystąpienia oraz wyrządzania przez nią szkody. Nawet zwolennicy tej koncepcji wskazują, że wątpliwości tego rodzaju powinny przemawiać przeciwko jej uwzględnieniu ${ }^{44}$. Udowodnienie ponad wszelką wątpliwość zdarzenia jedynie hipotetycznego jest ze swej istoty niewykonalne, albowiem nawet wysoce prawdopodobna hipoteza pozostaje jedynie hipotezą. Nie można zakładać niezmienności pozostałych okoliczności (warunków) występujących $\mathrm{w}$ stanie faktycznym, dlatego nieuzasadnione jest ograniczanie się jedynie do badania konsekwencji realnego zdarzenia szkodzącego oraz konsekwencji wystąpienia przyczyny rezerwowej. Dopuszczenie możliwości korygowania zakresu odpowiedzialności sprawcy szkody ze względu na hipotetyczne przyczyny rezerwowe oznaczałoby przyznanie hipotezie większej doniosłości niż faktom ${ }^{45}$. Ze względu na ontologiczną niemożność realnego istnienia hipotezy nie powinna ona być podstawą ograniczania rozmiaru szkody, która ma podlegać restytucji.

Za bardziej adekwatną metodę ustalania rozmiaru szkody należy uznać metodę obiektywną, której rezultat określa minimalną wartość szkody. Jednakże ze względu na dynamiczny charakter szkody oraz w związku z uwzględnieniem utraconych korzyści (lucrum cesans) rozmiar szkody ustalony z zastosowaniem

${ }^{43}$ H. Ciepła, R.M. Sarbiński, K. Sobczyk-Sarbińska, Roszczenia przystugujące bytym właścicielom tzw. gruntów warszawskich. Sposób ich dochodzenia w postępowaniu administracyjnym i sądowym, Warszawa 2013, s. 226.

44 J. Jastrzębski, O wyprzedzającej..., s. 634.

45 M. Wilejczyk, op. cit., s. 78. 
metody obiektywnej powinien zostać skorygowany metodą dyferencyjną, ale jedynie w zakresie zwiększenia jej rozmiaru. Przyjęcie takiego modelu wyklucza możliwość stosowania konstrukcji przyczynowości hipotetycznej oraz zmniejszenia rozmiaru szkody ze względu na hipotetyczną przyczynę rezerwową.

\section{Bibliografia}

Banaszczyk Z., [w:] Kodeks cywilny. Komentarz, t. 1, red. K. Pietrzykowski, Warszawa 2013.

Bieniek G., Odpowiedzialność cywilna za wypadki drogowe, Warszawa 2007.

Ciepła H., Sarbiński R.M., Sobczyk-Sarbińska K., Roszczenia przystugujące byłym właścicielom tzw. gruntów warszawskich. Sposób ich dochodzenia w postępowaniu administracyjnym i sąowym, Warszawa 2013.

Dybowski T., [w:] System prawa cywilnego, t. 3, cz. 1, red. Z. Radwański, Wrocław 1981.

Jastrzębski J., Glosa do wyroku Sądu Najwyższego z dnia 2 marca 2006 r., sygn. akt I CSK 90/05, „Palestra” 2007, nr 3/4.

Jastrzębski J., O wyprzedzającej przyczynowości, „Kwartalnik Prawa Prywatnego” 2003, nr 3.

Kaliński M., [w:] System Prawa Prywatnego, t. 6. Prawo zobowiąań - część ogólna, red. A. Olejniczak, Warszawa 2014.

Kaliński M., O btędach w stosowaniu konstrukcji tzw. causa superveniens, „Przegląd Sądowy” 2013, nr 1 .

Kaliński M., Szkoda na mieniu i jej naprawienie, Warszawa 2008.

Koch A., Komentarz do art. 361, [w:] Kodeks cywilny, t. 1. Komentarz do art. 1-449, red. M. Gutowski, wersja elektroniczna, uwaga 34-36, SIP Legalis.

Koch A., Metodologiczne zagadnienia zwiąku przyczynowego w prawie cywilnym, Poznań 1975.

Koch A., Zwiazek przyczynowy jako podstawa odpowiedzialności w prawie cywilnym, Warszawa 1975.

Lewaszkiewicz-Petrykowska B., Wyrządzenie szkody przez kilka osób, Warszawa 1978.

Machnikowski P., [w:] System Prawa Prywatnego, t. 6. Prawo zobowiazań - czesść ogólna, red. A. Olejniczak, Warszawa 2014.

Napierała J., Utracony zysk jako postać szkody w prawie niemieckim, „Ruch Prawniczy, Ekonomiczny i Socjologiczny" 1991, nr 4.

Napierała J., Z problematyki lucrum cesans w obrocie uspołecznionym, „Ruch Prawniczy, Ekonomiczny i Socjologiczny" 1983, nr 4.

Nederlander H., Schadensersatz bei hypothetischen Schadenserreignissen, „Archiv fur die civilistiche Praxis" 1954, nr 153.

Sobolewski P., [w:] Kodeks cywilny. Komentarz, t. 3A, red. K. Osajda, Warszawa 2017.

Stoll H., Kausalzusammenhang und Normzweck im Deliktrecht, Tübingen 1968.

Szpunar A., Odszkodowanie za szkodę majątkowa, Bydgoszcz 1998.

Szpunar A., Ustalenie odszkodowania wprawie cywilnym, Warszawa 1975.

Wilejczyk M., Przyczyna rezerwowa - niedopuszczalny prezent dla osoby odpowiedzialnej za szkodę, „Przegląd Sądowy” 2016, nr 6.

Winiarz J., Ustalenie wysokości odszkodowania, Warszawa 1962.

Wiśniewski T., [w:] Komentarz do kodeksu cywilnego. Księga trzecia. Zobowiązania, t. 1, red. G. Bieniek, Warszawa 2009.

Zagrobelny K., [w:] Kodeks cywilny. Komentarz, red. E. Gniewek, P. Machnikowski, Warszawa 2016.

Studenckie Prace Prawnicze, Administratywistyczne i Ekonomiczne 28, 2019

(C) for this edition by CNS 


\section{Akty prawne}

Ustawa dnia 23 kwietnia 1964 roku - Kodeks cywilny (tekst jedn. Dz.U. z 2018 r. poz. 1025 ze zm.).

\section{Orzecznictwo}

Wyrok SN z 16 lutego 1965 roku, sygn. akt I PR 330/64, Legalis nr 109421. Wyrok SN z 14 stycznia 2005 roku, sygn. akt III CK 193/04, Legalis nr 69525. Wyrok SN z 10 lutego 2009 roku, sygn. akt II PK 142/08, Legalis nr 238932. Wyrok SN z 11 marca 2009 roku, sygn. akt I CSK 363/08, Legalis nr 244054. Wyrok SN z 29 kwietnia 2010 roku, sygn. akt IV CSK 467/09, Legalis nr 237026.

\section{Hypothetical causality. The problem of determining the scope of tort liability, in the situation of the so-called reserve reason (causa superveniens)}

\section{Summary}

The study presents the problem of hypothetical causation. The issue of the reserve reason as a factor affecting the extent of damage was presented from the perspective of the objective method and the differential method of determining the extent of damage. According to the author, determining the extent of damage only by means of the differential method leads to a result contrary to the social axiological assessment, which can not be considered binding. The omission of the differential method in the article, however, does not contradict the dynamic character of the damage. The article states that the extent of damage determined by the objective method - constituting the minimum extent of damage - should be corrected by means of a differential method. Therefore, reserve reason (causa superveniens) can not lead to a reduction in the scope of the obligation to repair the damage by the entity responsible for the basic event. 